\title{
Special issue on toxic metal pollution
}

Metals and metalloids are an integral part of the Earth's crust. Some of these elements are of great concern due to their high toxicity and threat to humans, wildlife, and the ecosystem. For simplicity, the term toxic metals is adopted to represnt both toxic metals and metalloids in this special issue. Toxic metals include not only the ones that are toxic and have no biological role (e.g., lead $(\mathrm{Pb})$, mercury $(\mathrm{Hg})$, cadmium $(\mathrm{Cd})$, arsenic $(\mathrm{As}))$, but also some dietary minerals, which are toxic at high concentrations (e.g., maganese $(\mathrm{Mn})$, copper $(\mathrm{Cu})$, iron $(\mathrm{Fe})$, selenium $(\mathrm{Se}))$. Mercury, Cd, chromium $(\mathrm{Cr}), \mathrm{Pb}, \mathrm{As}, \mathrm{zinc}(\mathrm{Zn})$, tin $(\mathrm{Sn})$, and $\mathrm{Cu}$ are the most worrisome toxic metals due to their high toxicity, pevalent existence and in some cases bioaccumulation through the food chain. With the fast growth of economy, toxic metal pollution has emerged as one of the most alarming environmental problems over the past several decades in China. Elevated levels of Pb have been observed in human blood samples from many provinces in China. Arsenicosis in China, mainly caused by the contamination of drinking water by arsenic, has been regarded as an endemic disease throughout the nation in 1994. Long-term mercury mining in Guizhou has resulted in elevated levels of mercury in surrounding areas. Concentrations of total mercury in rice grains can reach as high as $0.57 \mathrm{mg} / \mathrm{kg}$. In January 2012, large amounts of Cd were leaked into the Longjiang River in Guangxi Zhuang Autonomous Region, resulting in severe economic losses and public health impacts.

Metals in the environment originate from both natural and anthropogenic sources. Natural sources include volcanoes, degradation of minerals, forest fires, and evaporation from soil and water surfaces. For some toxic metals, such as As and $\mathrm{Hg}$, natural sources can contribute significantly to their levels in the environment. Anthropogenic sources of toxic metals include coal-fired power plants, mining and other metallurgic activities, agricultural use of toxic metals, waste incineration, and landfills. Anthropogenic sources are commonly considered to be responsible for the increasing pollution of most toxic metals in recent years. For example, most of the $\mathrm{Hg}$ emission in China is thought to be from nonferrous metal smelting and coal consumption. Decreasing anthropogenic emissions is the most effective tool to mitigate the pollution of toxic metals.

Toxic metals, when present in excessive concentrations in the environment, may pose a great threat to most organisms, including microorganisms, plants, animals, and humans. They can affect organisms via a variety of pathways, e.g., inhibiting enzyme activities and cell metabolism, decreasing the photosynthetic activity of plants, and elevating the production of reactive oxygen species. Uptake of excess toxic metals by humans can cause severe damage to human organs, such as liver, kidney, digestion system, and nervous system.

In consideration of the severe toxic metal pollution in China, prevention and management of toxic metal pollution have been set as one of the key goals in China's "12th 5-Year Plan" (2011-2015). A designated project, entitled "the 12th 5-Year Plan for Comprehensive Prevention and Control of Heavy Metal Pollution” was issued by the Chinese government in 2011. This project aims to control the total discharge of five toxic metals ( $\mathrm{Pb}, \mathrm{Hg}, \mathrm{Cd}, \mathrm{Cr}$ and $\mathrm{As})$ to the environment. This special issue of Chinese Science Bulletin was intended to address recent advances in the study of toxic metal pollution, including six aspects: pollution status, advanced analytical techniques, biogeochemical cycling, toxicity, remediation and management, and maximum allowable loading amount.

CAI Yong \& LI YanBin

Department of Chemistry and Biochemistry \& Southeast Environmental Research Center Florida International University, Miami, FL 33199, USA

Open Access This article is distributed under the terms of the Creative Commons Attribution License which permits any use, distribution, and reproduction in any medium, provided the original author(s) and source are credited. 